\title{
The $\alpha 2$-HeremansSchmid glycoprotein (AHSG) promotes growth in head and neck squamous cell carcinoma (HNSCC)
}

\author{
Pamela D Thompson', Amos Sakwe1, Josiah Ochieng ${ }^{1}$, Siddharth Pratap ${ }^{2}$, Dana R Marshall ${ }^{3^{*}}$ \\ From 12th Annual UT-ORNL-KBRIN Bioinformatics Summit 2013 \\ Buchanan, TN, USA. 22-24 March 2013
}

\section{Background}

AHSG is a calcium-binding glycoprotein synthesized primarily by the liver [1-3] and secreted into serum [1-3]. Primarily known for its role in bone growth and remodeling, it is also reported to be involved in the progression of breast and lung cancer with these cells utilizing the liver synthesized form $[1,4,5]$. Uniquely, HNSCC cells synthesize their own AHSG, suggesting autocrine signaling fueling cell proliferation and movement. Here we present data showing the presence of AHSG mRNA in HNSCC cell line SQ20B and phenotypic and transcriptomic changes resulting from shRNA knockdown of AHSG protein expression.

\section{Materials and methods}

HNSCC cell line SQ20B was transduced with pGIPZ empty vector or pGIPZ with different AHSG target sequences to generate AHSG deficient cell lines. Depletion of AHSG was confirmed by immunoblot using Meridian AHSG polyclonal antibody and immunocytochemical staining for vector-encoded GFP. To evaluate the physiological loss of AHSG on cell biology, cells were cultured in serum free-media, as serum is a source of AHSG in all animals. Proliferation, migration and invasion were evaluated using standard methodologies. Transcriptomic analysis of cell lines was performed using the Affymetrix Human Gene 2.0 ST chip.

\section{Results}

The role of AHSG in cell proliferation, invasion and migration was evaluated for wildtype SQ20B (SQ20BWT), SQ20-B with empty vector (SQ20B-EV), SQ20B expressing $50 \%$ or $20 \%$ of AHSG expressed by SQ20BEV (SQ20B-AH50 and -AH20 respectively). Decreased AHSG expression resulted in decreased proliferation, migration and invasion of SQ20B cells (Table 1).

Transcriptomic analysis identified genes associated with cancer and cellular movement as two of the top biofunction categories associated with AHSG molecular function.

\section{Conclusions}

AHSG affects in vitro cellular properties associated with metastatic potential in vivo. Transcriptomic analysis has

Table 1 SQ20B-WT, -EV, -AH50 and -AH20 cell lines were evaluated for properties associated with proliferation, migration and invasion. All cell lines were compared to SQ20B-WT

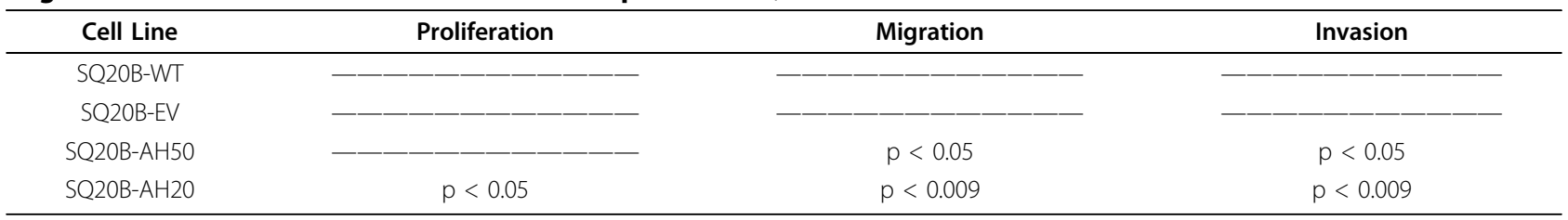

\footnotetext{
* Correspondence: dmarshall@mmc.edu

${ }^{3}$ Department of Pathology, Anatomy and Cell Biology, Meharry Medical

College, Nashville, TN, 37208, USA

Full list of author information is available at the end of the article
} 
Table 2 Top biofunctions calculated (Ingenuity Pathways Analysis) from gene list generated by comparison of SQ20B-AH20 and SQ20B-WT for genes differentially expressed at $p<0.05$ (Benjamini and Hochberg multiple testing correction) and fold difference $\geq 1.5$

\begin{tabular}{|c|c|c|}
\hline Diseases and Disorders & p-value & \# Molecules \\
\hline $\begin{array}{c}\text { Dermatological Diseases and } \\
\text { Conditions }\end{array}$ & $2.00 \mathrm{E}-08-1.47 \mathrm{E}-02$ & 59 \\
\hline Cancer & 1.90E $-07-1.55 \mathrm{E}-02$ & 103 \\
\hline Reproductive System Disease & $2.31 \mathrm{E}-07-1.48 \mathrm{E}-02$ & 54 \\
\hline Endocrine System Disorders & $3.17 \mathrm{E}-07-2.29 \mathrm{E}-03$ & 28 \\
\hline Inflammatory Responses & $7.32 \mathrm{E}-06-1.62 \mathrm{E}-02$ & 48 \\
\hline \multicolumn{3}{|l|}{$\begin{array}{c}\text { Molecular and Cellular } \\
\text { Functions }\end{array}$} \\
\hline Cellular Movement & $5.75 \mathrm{E}-06-1.62 \mathrm{E}-02$ & 61 \\
\hline Lipid Metabolism & $6.04 \mathrm{E}-05-1.47 \mathrm{E}-02$ & 24 \\
\hline Molecular Transport & $6.04 \mathrm{E}-05-1.59 \mathrm{E}-02$ & 41 \\
\hline Small Molecule Biochemistry & $6.04 \mathrm{E}-05-1.51 \mathrm{E}-02$ & 36 \\
\hline $\begin{array}{c}\text { Cell-To-Cell Signaling and } \\
\text { Interaction }\end{array}$ & $8.26 \mathrm{E}-05-1.59 \mathrm{E}-02$ & 46 \\
\hline
\end{tabular}

identified highly relevant transcriptomic programs of expression that will highlight new cellular processes that are likely associated with metastasis of HNSCC.

\section{Acknowledgements}

This work was supported by grants from the SC1 CA134018-01 (JO); DOD W81XWH-07-1-0254 (JO); and U54 CA091408 (subproject DM). PT supported in part by the Vanderbilt CTSA grant UL1 TR000445 from NCRR/NIH; and 5 T32 HL007735-15.

Microarray processed at Vanderbilt University Genomic Science Resource Core, Nashville, TN, 37208.

\section{Authors' details}

'Department of Biochemistry and Cancer Biology, Meharry Medical College, Nashville, TN, 37208, USA. ${ }^{2}$ Bioinformatics and Proteomics Core, Department of Microbiology and Immunology, Meharry Medical College, Nashville, TN, 37208, USA. ${ }^{3}$ Department of Pathology, Anatomy and Cell Biology, Meharry Medical College, Nashville, TN, 37208, USA.

Published: 22 October 2013

\section{References}

1. Guillory B, Sakwe AM, Saria M, Thompson P, Adhiambo C, Koumangoye R, Ballard B, Binhazim A, Cone C, Jahanen-Dechent W, Ochieng J: Lack of fetuin-A (alpha2-HS-glycoprotein) reduces mammary tumor incidence and prolongs tumor latency via the transforming growth factor-beta signaling pathway in a mouse model of breast cancer. Am J Pathol 2010, 177(5):2635-2644.

2. Schafer C, Heiss A, Schwarz A, Westenfeld R, Ketteler M, Floege J, MullerEsterl W, Schinke T, Jahnen-Dechent W: The serum protein alpha 2Heremans-Schmid glycoprotein/fetuin-A is a systemically acting inhibitor of ectopic calcification. J Clin Invest 2003, 112(3):357-366.

3. Swallow CJ, Partridge EA, Macmillan JC, Tajirian T, DiGuglielmo GM, Hay K, Szweras M, Jahnen-Dechent W, Wrana JL, Redston M, Gallinger S, Dennis JW: alpha2HS-glycoprotein, an antagonist of transforming growth factor beta in vivo, inhibits intestinal tumor progression. Cancer Res 2004, 64(18):6402-6409.

4. Brown WM, Dziegielewska KM, Saunders NR, Christie DL, Nawratil P, MüllerEsterl W: The nucleotide and deduced amino acid structures of sheep and pig fetuin. Common structural features of the mammalian fetuin family. Eur J Biochem 1992, 205(1):321-331.
5. Kundranda MN, Henderson M, Carter K, Gorden L, Binhazim A, Ray S, Baptiste T, Shokrani M, Leite-Browning ML, Jahnen-Dechent W,

Matrisiann LM, Ochieng J: The serum glycoprotein fetuin-A promotes Lewis lung carcinoma tumorigenesis via adhesive-dependent and adhesive-independent mechanisms. Cancer Res 2005, 65(2):499-506.

\section{doi:10.1186/1471-2105-14-S17-A7}

Cite this article as: Thompson et al:: The $\alpha 2$-HeremansSchmid

glycoprotein (AHSG) promotes growth in head and neck squamous cell carcinoma (HNSCC). BMC Bioinformatics 2013 14(Suppl 17):A7.

\section{Submit your next manuscript to BioMed Central and take full advantage of:}

- Convenient online submission

- Thorough peer review

- No space constraints or color figure charges

- Immediate publication on acceptance

- Inclusion in PubMed, CAS, Scopus and Google Scholar

- Research which is freely available for redistribution 